\title{
Evaluation of Mechanical Properties and Machinability Analysis of A/ 6061 Hybrid Composite
}

\author{
P.V. Rajesh ${ }^{1 *}$, M.Sriram Prasanth ${ }^{2}$, V.Sam Daniel ${ }^{3}$ and C.M.Saravanan ${ }^{4}$ \\ ${ }^{1,2}$ Assistant Professor, ${ }^{3,4}$ UG Scholars, Department of Mechanical Engineering, Saranathan College of Engineering, Trichy-620012, India \\ Received 02 Jan 2018, Accepted 01 March 2018, Available online 02 March 2018, Vol.6 (March/April 2018 issue)
}

\begin{abstract}
Aluminium Matrix Composites are extensively used due to their desirable properties like low weight, low cost, high strength to weight ratio, good corrosion resistance, good thermal conductivity and high stiffness. Their applications are diversified in production, thermal, marine and automobile industries. Aluminium is extensively used in ships, aircrafts, cars, electrical wires and household utensils because it is abundant in nature. In the present study, Aluminium alloy Al6061 Hybrid Composites reinforced with Boron carbide and Coconut shell ash are fabricated to replace the individual Aluminium alloy Al6061. For that various tests to determine properties such as strength, hardness, wear and corrosion resistance are conducted on composite samples which make them fit to be used in aircraft window frames by reviewing various literatures. In addition to above, machinability analysis is performed on all the specimens and their surface roughness is measured. Based on the results obtained, we can come to a conclusion that the aluminium composite has superior properties than individual Al6061 alloy.
\end{abstract}

Keywords: Aluminium Matrix Composites; Aircraft; Boron carbide; Coconut shell ash; Machinability; Tensile strength; Hardness; Corrosion resistance

\section{Introduction}

A Composite material can be formed by combining two or more dissimilar materials together. The mechanical properties of the composites will be better than the individual components. The composite materials will be composed of two or more phases. They are matrix phase and reinforcement phase [1].

A Metal matrix composite is one of type of composite in which the matrix phase is predominantly a metal or a metal alloy. The metal is the base material which constitutes the major part and the minor constituents are reinforcements that can be in the form of particles, whiskers, continuous and discontinuous fibres [2]. The reinforcement material will be a ceramic or organic compound. The MMC consists of superior properties such as high strength, high stiffness, high electrical and thermal conductivity, greater resistance to corrosion, oxidation and wear when compared to the base material. A hybrid composite is one which involves more than two constituting materials.

Aluminium Matrix Composites are extensively used due to their desirable properties like low weight, low cost, high strength to weight ratio, good corrosion resistance, good thermal conductivity and high stiffness. Their

*Corresponding author's ORCID ID: 0000-0002-4858-9032 DOI: https://doi.org/10.14741/ijmcr/v.6.2.1 applications are diversified in production, thermal, marine and automobile industries. To name a few, ships, aircrafts, cars, electrical wires and household utensils use aluminium because it is the most abundant material on earth.

\section{Selection of materials}

\section{A. Matrix}

The matrix material to be used was chosen as Al6061 which is a precipitation hardened aluminium alloy, containing iron, silicon and chromium as its major alloying elements as indicated in Table 1. It has good mechanical properties and exhibits good weldability, good formability and high corrosion resistance [3].

Table 1.Composition of Al 6061

\begin{tabular}{|c|c|}
\hline Constituents & Percentage \\
\hline Manganese (Mn) & $0.108 \%$ \\
\hline Iron (Fe) & $0.125 \%$ \\
\hline Copper (Cu) & $0.392 \%$ \\
\hline Magnesium (Mg) & $0.970 \%$ \\
\hline Silicon (Si) & $0.620 \%$ \\
\hline Chromium (Cr) & $0.079 \%$ \\
\hline Others (Total) & $0.04 \%$ \\
\hline Aluminium (Al) & $97.7 \%$ \\
\hline
\end{tabular}

250|Int. J. of Multidisciplinary and Current research, Vol.6 (March/April 2018) 


\section{B. Reinforcement}

The materials selected to be reinforced into the metallic matrix are Boron Carbide having particle size of $150 \mu \mathrm{m}$ and Coconut Shell Ash having particle size of $75 \mu \mathrm{m}$.

Boron carbide is an industrial ceramic which is the third hardest material next to diamond and cubic boron nitride [4]. It is reinforced in the Al6061 matrix to increase strength, hardness, stiffness, wear resistance and impact strength. Its attractive properties are listed in Table 2.

Table 2 Properties of boron carbide

\begin{tabular}{|c|c|c|}
\hline Properties & Units & Values \\
\hline Density & $\mathrm{g} / \mathrm{cm} 3$ & 2.52 \\
\hline Melting point & ${ }^{\circ} \mathrm{C}$ & 2450 \\
\hline Fracture toughness & $\mathrm{MPaVm}$ & 3.0 \\
\hline $\begin{array}{c}\text { Thermal } \\
\text { Conductivity }\end{array}$ & $\mathrm{W} / \mathrm{mK}$ & 40 \\
\hline Vickers Hardness & & 3850 \\
\hline Tensile strength & $\mathrm{MPa}$ & 350 \\
\hline Elastic modulus & $\mathrm{GPa}$ & 450 \\
\hline
\end{tabular}

Coconut shell is an agricultural waste and is available in very large quantities throughout the tropical countries of the world. Moreover, coconut is becoming an important agricultural product for tropical countries around the world as a new source of energy-biofuel. Previously, coconut shell was burnt as a means of solid waste disposal which contributed significantly to $\mathrm{CO} 2$ and methane emissions. However, as the cost of fuel oil, natural gas and electricity supply has increased and become erratic, coconut shell has come to be regarded as source of fuel rather than refuse.

The coconut shell was first crushed and then burnt for two hours to get charcoal. Then the charcoal was heated in a furnace at $1300^{\circ} \mathrm{C}$ by placing it in a graphite crucible for one hour to get the ash.

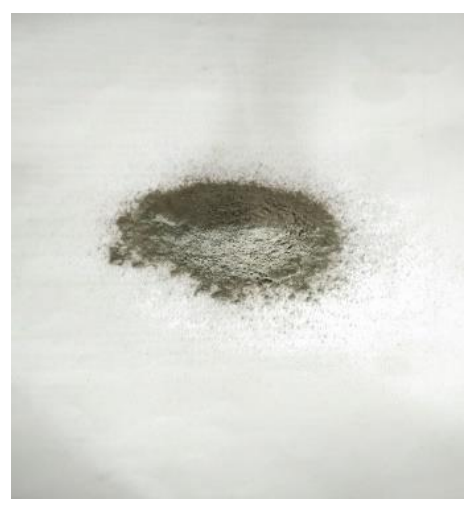

Figure 1 Coconut Shell Ash

The obtained silica-rich coconut shell ash having a density of $2.05 \mathrm{~g} / \mathrm{cm} 3$, is thereafter used as a reinforcement material for the preparation of composites. The chemical composition of the rice husk ash obtained is shown in Table 3.
Table 3 Chemical composition of coconut shell ash

\begin{tabular}{|c|c|}
\hline Chemical Composition & $\%$ \\
\hline Silicon dioxide $\left(\mathrm{SiO}_{2}\right)$ & 55.0 \\
\hline Potassium oxide $\left(\mathrm{K}_{2} \mathrm{O}\right)$ & 19.2 \\
\hline $\mathrm{Ca}^{2+}$ & 12.9 \\
\hline $\mathrm{K}^{+}$ & 13.1 \\
\hline
\end{tabular}

Both Boron Carbide and Rice Husk Ash are used together as reinforcements, because:

Boron Carbide is expensive

Agricultural wastes along with ceramics give improved mechanical properties

Agricultural wastes can give only marginal increase in strength and hardness, if dispersed in Aluminium matrix individually.

Coconut Shell Ash has low elastic modulus

\section{Fabrication process}

Stir casting is the most popular commercial method of producing aluminum based composites. In this method, pre-heated ceramic particulates are incorporated into the vortex of the molten matrix created by a rotating impeller.

Table 4 Compositions of composite specimens

\begin{tabular}{|c|c|c|c|c|}
\hline $\begin{array}{c}\text { Specime } \\
\text { ns }\end{array}$ & $\begin{array}{c}\text { Percentag } \\
\text { e of } \\
\text { Reinforce } \\
\text { ment }\end{array}$ & $\begin{array}{c}\text { Weight \% } \\
\text { of } \\
\text { Al6061 }\end{array}$ & $\begin{array}{c}\text { Weight } \\
\% \text { of } \\
\text { B }_{4} \text { C }\end{array}$ & $\begin{array}{c}\text { Weight } \\
\text { \% of } \\
\text { CSA }\end{array}$ \\
\hline I & 0 & 100 & 0 & 0 \\
\hline II & 5 & 95 & 0 & 5 \\
\hline III & 10 & 90 & 0 & 10 \\
\hline IV & 4 & 96 & 1 & 3 \\
\hline V & 4 & 96 & 2 & 2 \\
\hline VI & 4 & 96 & 3 & 1 \\
\hline VII & 8 & 92 & 2 & 6 \\
\hline VIII & 8 & 92 & 4 & 4 \\
\hline IX & 8 & 92 & 6 & 2 \\
\hline
\end{tabular}

The stir casting process starts with the preheating of graphite crucible in a coal-fired furnace for 20 minutes. The Coconut Shell Ash and Boron Carbide particles were initially preheated separately at a temperature of $250^{\circ} \mathrm{C}$ to remove moisture and to help even distribution within Al6061 alloy. The Al6061 alloy billets were charged into the furnace and heated to a temperature of $750 \pm 30^{\circ} \mathrm{C}$ (i.e) above the liquidus temperature of the alloy to ensure that the alloy melts completely. Now with the help of electrical stirrer, the molten alloy is stirred at a constant speed of $450 \mathrm{rpm}$ to create vortex. The preheated Coconut Shell Ash and Boron Carbide particles are then charged into the melt at constant pour rate and stirring of 
the slurry was performed manually for 5-10 minutes. Then the melted matrix and reinforced particles are poured into the preheated mould and the pouring temperature should be maintained at $680^{\circ} \mathrm{C}$. After solidification, the composite can be cut into different shapes and sizes as per requirements.

\section{Measurement of density}

Density is an important physical property of any material. For our composite, measurement of density is even more important as the ultimate aim is to reduce weight of aircraft parts. The density of the composite is related to the individual densities of the matrix as well as reinforced material. (i.e) Al6061 and B4C-Coconut Shell Ash respectively. For measuring density, the composite samples of different compositions are milled and grinded to perfect cubes with specific dimensions as per 'ASTM Standard practice for preparation of test materials A370'.

\section{Experimental density}

Experimental density or particle density of the composite specimen is calculated using 'Archimedes' principle'. Initially for measuring the density, test samples of different compositions are cut from the specimen, grinded and highly polished before weighing. They are made into perfect cubes having dimension (Ixbxt) $10 \times 10 \times 10 \mathrm{~mm}$. The mass of the composite is measured using a highly accurate digital mass balance of unit weight 0.01 .

$\rho m m c=(m /(m-m 1)) \times \rho H 2 O$

Where,

pmmc is the density of the composite,

' $\mathrm{m}$ ' is the mass of the composite sample in air,

' $m 1$ ' is the apparent mass of the same composite suspended in distilled water

' $\mathrm{\rho H} 2 \mathrm{O}$ ' is the density of distilled water (at 293K) is 998 $\mathrm{kg} / \mathrm{m}^{3} . \mathrm{I}=$ length of the sample in $\mathrm{mm}$.

$\mathrm{b}=$ breadth of the sample in $\mathrm{mm}$ and $\mathrm{t}=$ thickness of the sample in $\mathrm{mm}$.

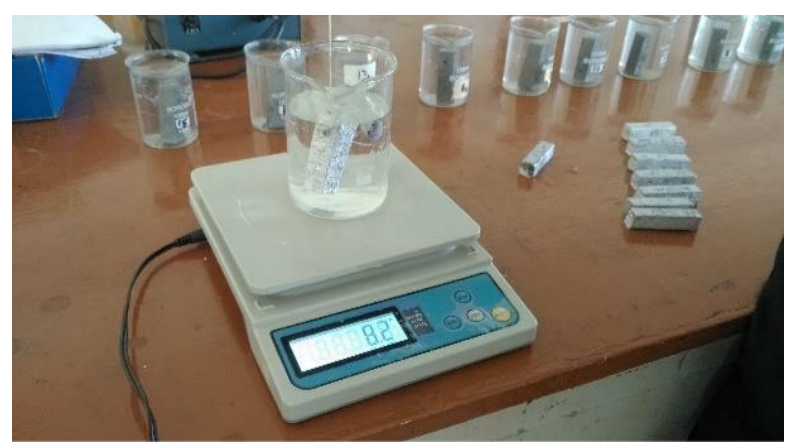

Figure 2 Determination of apparent density
Table 5 Determination of density

\begin{tabular}{|c|c|c|c|}
\hline Specimen & $\begin{array}{c}\text { Mass of the sample } \\
\text { in air } \\
\text { (g) }\end{array}$ & $\begin{array}{c}\text { Apparent mass of the } \\
\text { sample in distilled } \\
\text { water } \\
\text { (g) }\end{array}$ & $\begin{array}{c}\text { True } \\
\text { density } \\
\text { (g/cc) }\end{array}$ \\
\hline I & 20.9 & 12.95 & 2.63 \\
\hline II & 20.8 & 11.08 & 2.14 \\
\hline III & 21.5 & 10.53 & 1.96 \\
\hline IV & 20.3 & 12.24 & 2.52 \\
\hline V & 21.3 & 12.71 & 2.48 \\
\hline VI & 21.1 & 12.98 & 2.6 \\
\hline VII & 20.3 & 11.77 & 2.38 \\
\hline VIII & 20.3 & 11.91 & 2.42 \\
\hline IX & 20.6 & 12.07 & 2.40 \\
\hline
\end{tabular}

\section{Tests conducted}

The specimens fabricated by Stir casting is cut and machined into test samples of required shape and dimensions for the conduction of various tests.

\section{A. Mechanical tests}

\section{(i)Tensile test}

Tension means pulling force. The tensile test is done in a Universal Testing (model: M3320; range: 0-40 kN) to determine the tensile strength of the specimen. The specimen to be tested is fastened to the two end-jaws of the UTM. Now the load is applied gradually on the specimen by means of pulling the movable crosshead, till the specimen fractures. The corresponding extension of the composite specimen is also noted.

Ultimate Tensile strength = Maximum load given to specimen/ Area of cross section

\section{(ii) Brinell Hardness}

Hardness test is done on a specimen to know its ability to resist wear, abrasion and indentation. The Brinell hardness is measured from an indentation produced in the composite by applying a constant load of $500 \mathrm{kgf}$ on steel ball indenter in contact with the surface of the specimen for 10 seconds. The test is conducted as per ASTM standards for Brinell hardness testing E10. The indentation in the specimen surface is calculated from the formula:

Brinell Hardness number $=\frac{2 P}{\pi D[D-\sqrt{(D 2-d 2)}]}$

where,

$P=$ load applied on indenter (500 kgf)

$\mathrm{D}=$ diameter of steel ball indenter $(10 \mathrm{~mm})$

$\mathrm{d}=$ diameter of ball impression in $\mathrm{mm}$. 


\section{(iii) Charpy Impact test}

Impact strength is the capacity of a material to withstand blows without fracture. The impact test is done as per Standard test methods for notched bar tensile strain Impact test method ASTM E23 in Impact testing machine. In impact test, a notch is cut in the specimen upto $2 \mathrm{~mm}$ which is struck by a single blow in testing machine. The energy absorbed in breaking the specimen can be measured from the scale provided in the machine. In Charpy test of impact strength, the test sample is fixed horizontally to the machine base and the striking hammer is blown to hit the specimen behind the v-notch.

\section{(iv) Corrosion test}

The corrosion behaviour of the composites is studied by weight loss method using mass loss and corrosion rate measurements in both acidic and basic environments. The corrosion test will be carried out by immersion of the test specimens in $1 \mathrm{~N} \mathrm{HCl}(3.6 \mathrm{ml}$ in $100 \mathrm{ml}$ of distilled water) and $1 \mathrm{~N} \mathrm{NaOH}(4 \mathrm{~g}$ in $100 \mathrm{ml}$ of distilled water) solutions which will be prepared following standard procedures. The specimens for the test are cut to size $50 \times 12 \times 12 \mathrm{~mm}$ and then mechanically polished with emery papers from 150 down to 600 grit sizes to produce a smooth surface. The samples are de-greased with acetone, rinsed in distilled water, and then dried in air before immersion in still solutions at room temperature $\left(25^{\circ} \mathrm{C}\right)$. The solutionto-specimen surface area ratio will be about $150 \mathrm{ml} \mathrm{cm}^{-2}$, and the corrosion setups are exposed to atmospheric air for the duration of the immersion test. The weight loss readings will be monitored for a period of 24 hours. The mass loss $\left(\mathrm{mg} / \mathrm{cm}^{2}\right)$ for each sample will be evaluated in accordance with ASTM G31 Standard practice for lab immersion corrosion testing of metals following the relation:

$\mathrm{m} . \mathrm{I}=\mathrm{mi}-\mathrm{mf}$

where,

$\mathrm{m} . \mathrm{l}$ is the mass loss $\left(\mathrm{mg} / \mathrm{cm}^{2}\right), \mathrm{mi}$ is the initial weight $(\mathrm{g})$ and $\mathrm{mf}$ is the final weight $(\mathrm{g})$.

Corrosion rate for each sample will be evaluated from the weight loss measurements:

$C . R=K W / \rho A T$

where,

C. $R$ is corrosion rate ( $\mathrm{mm}$ per year),

$\mathrm{W}$ is weight loss after exposure time ( $\mathrm{mi}-\mathrm{mf})(\mathrm{g})$,

$\rho$ is the density of the composite (initial mass/volume) $\left(\mathrm{g} / \mathrm{cm}^{3}\right)$,

$A$ is the area of the sample (length $\mathrm{x}$ breadth of the facing side) $\left(\mathrm{cm}^{2}\right)$,
$\mathrm{T}$ is time of exposure (hours), and

$\mathrm{K}$ is a constant equal to 87500 .

\section{Result and tabulation}

Table 6 Tensile Test Results

\begin{tabular}{|c|c|c|c|c|c|c|c|c|c|}
\hline Specimen & I & II & III & IV & V & VI & VII & VIII & IX \\
\hline $\begin{array}{c}\text { Ultimate } \\
\text { Tensile } \\
\text { Strength (MPa) }\end{array}$ & 105 & 86 & 78 & 84 & 92 & 101 & 80 & 96 & 107 \\
\hline
\end{tabular}

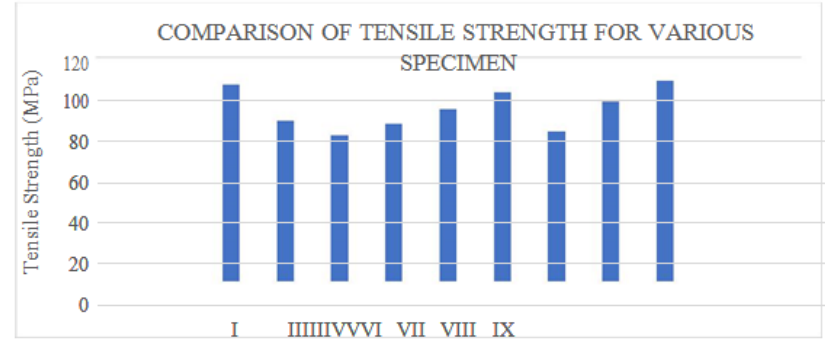

Figure 3 Tensile test results

Fig 3 shows the effect of weight fraction of various combinations of reinforcement materials on the tensile strength. The results show a fluctuation in tensile strength with the addition of reinforcement particles in which $92 \% \mathrm{Al}+6 \% \mathrm{~B} 4 \mathrm{C}+2 \% \mathrm{CSA}$ shows best result.

Table 7 Brinell hardness test results

\begin{tabular}{|l|c|c|c|c|c|c|c|c|c|}
\hline Specimen & I & II & III & IV & V & VI & VII & VIII & IX \\
\hline Hardness & 44.85 & 60.53 & 50.32 & 47.47 & 50.32 & 53.43 & 47.47 & 56.82 & 53.43 \\
\hline
\end{tabular}

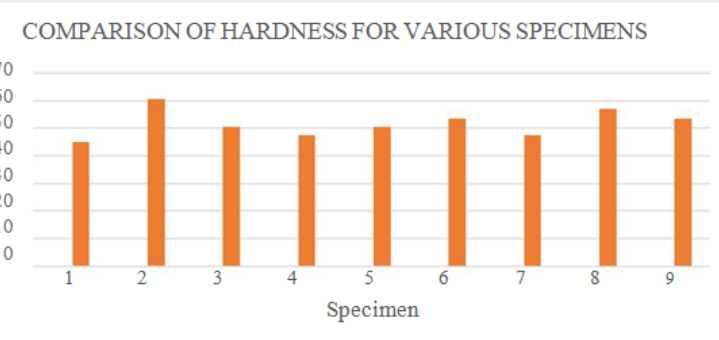

Figure 4 Brinell hardness test results

Fig. 4 shows the effect of weight fraction of various combinations of reinforcement materials on the hardness. The results show a fluctuation in hardness with the addition of reinforcement particles in which $90 \% \mathrm{Al}+10 \% \mathrm{CSA}$ shows best result.

Table 8 Charpy impact test results

\begin{tabular}{|c|c|c|c|c|c|c|c|c|c|}
\hline Specimen & $\mathrm{I}$ & $\mathrm{II}$ & $\mathrm{III}$ & $\mathrm{IV}$ & $\mathrm{V}$ & $\mathrm{VI}$ & $\mathrm{VII}$ & $\mathrm{VIII}$ & $\mathrm{IX}$ \\
\hline $\begin{array}{c}\text { Impact } \\
\text { Strength } \\
\text { (J/mm }\end{array}$ & 0.2 & 0.475 & 0.35 & 0.375 & 0.425 & 0.475 & 0.4 & 0.425 & 0.5 \\
\hline
\end{tabular}




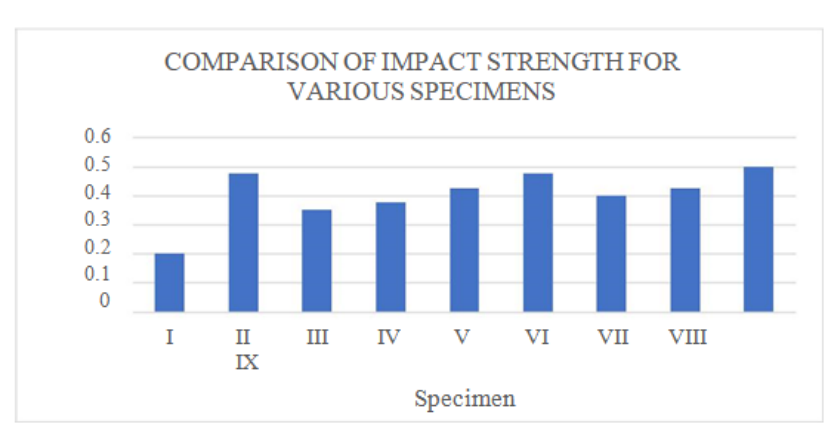

Figure 5 Impact test results

Fig. 5 shows the effect of weight fraction of various combinations of reinforcement materials on the impact strength. The results show a fluctuation in impact energy with the addition of reinforcement particles in which $92 \% \mathrm{Al}+6 \% \mathrm{~B} 4 \mathrm{C}+2 \% \mathrm{CSA}$ shows best result.

Table 9 Corrosion test results

\begin{tabular}{|c|c|c|c|c|c|c|c|c|}
\hline \multirow[t]{2}{*}{ Specimen } & \multicolumn{2}{|c|}{$\begin{array}{l}\text { Initial Weight } \\
\mathrm{m}_{\mathrm{i}}\end{array}$} & \multicolumn{2}{|c|}{$\begin{array}{c}\text { Final } \\
\text { Weight } \\
m_{f} \\
\end{array}$} & \multicolumn{2}{|c|}{$\begin{array}{c}\text { Mass Loss } \\
m_{i}-m_{f}\end{array}$} & \multicolumn{2}{|c|}{$\begin{array}{c}\text { Corrosion Rate } \\
C_{R}=K W / \rho A T\end{array}$} \\
\hline & A & B & A & B & A & B & A & B \\
\hline 1 & 20.9 & 20.9 & 20.5 & 19.7 & 0.4 & 1.2 & 1860.1 & 4030.3 \\
\hline 2 & 19.2 & 20.9 & 18.8 & 19.7 & 0.4 & 1.2 & 1135.8 & 3407.3 \\
\hline 3 & 19.7 & 21.6 & 19.1 & 20.3 & 0.6 & 1.3 & 1550.1 & 3720.2 \\
\hline 4 & 20.4 & 20.3 & 19.8 & 19.1 & 0.6 & 1.2 & 1446.7 & 2893.5 \\
\hline 5 & 21.4 & 21.2 & 20.9 & 20.1 & 0.5 & 1.1 & 1225.1 & 2695.2 \\
\hline 6 & 21.4 & 21.1 & 20.8 & 19.9 & 0.6 & 1.2 & 1402.2 & 2804.5 \\
\hline 7 & 21.5 & 20.3 & 21 & 19.3 & 0.5 & 1 & 1276.5 & 2553.1 \\
\hline 8 & 20.5 & 20.3 & 20 & 19.2 & 0.5 & 1.1 & 1255.4 & 2762.0 \\
\hline 9 & 20.8 & 20.6 & 20.2 & 19.6 & 0.6 & 1 & 1012.7 & 2531.8 \\
\hline
\end{tabular}

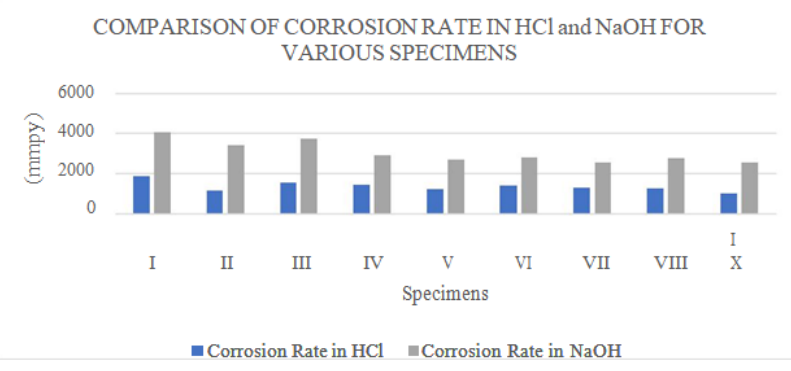

Figure 6 Corrosion test results

Fig. 6 shows the effect of weight fraction of various combinations of reinforcement materials on the corrosion rate when immersed in both $\operatorname{acid}(A)$ and base(B) solutions. Basic solution corrodes more than the acidic solution. The results show a fluctuation in corrosion resistance with the addition of reinforcement particles in which $90 \% \mathrm{Al}+10 \% \mathrm{~B} 4 \mathrm{C}$ shows best result.

\section{Machinability analysis}

\section{A. Machinability}

The term machinability refers to the ease with which a metal can be cut (machined) permitting the removal of the material with a satisfactory finish at low cost.
Materials with good machinability require little power to cut, can be cut quickly, easily obtain a good finish, and do not wear the tooling much; such materials are said to be free machining.

\section{B. Machinability analysis}

Machinability can be difficult to predict because machining has so many variables. There are many factors affecting machinability, but no widely accepted way to quantify it. Machinability characteristics of any tool-work pair is to be judged by:

- magnitude of the cutting forces tool wear or tool life

- surface finish

- magnitude of cutting temperature chip forms

\section{Milling}

Milling is the machining process of using rotary cutters to remove material from a workpiece by advancing (or feeding) in a direction at an angle with the axis of the tool. It covers a wide variety of different operations and machines, on scales from small individual parts to large, heavy-duty gang milling operations. It is one of the most commonly used processes in industry and machine shops today for machining parts to precise sizes and shapes.

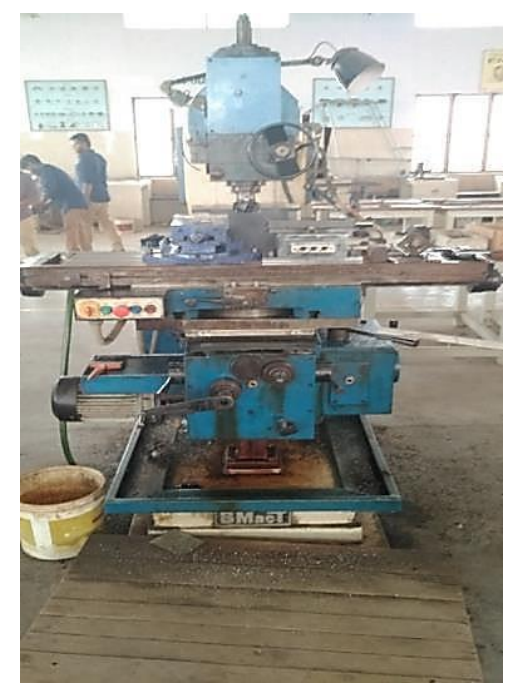

Figure 7 Vertical milling machine

\section{Material Removal Rate (MRR)}

The Material Removal Rate can be defined as the amount of material removed divided by the machining time.

$$
M R R=(m i-m f) / t
$$

where

$\mathrm{mi}$ - mass of the material before milling $(\mathrm{g})$

$\mathrm{mf}$ - mass of the material after milling $(\mathrm{g})$

$\mathrm{t}$ - machining time ( $\mathrm{min})$ 
Table 10 Material removal rate

\begin{tabular}{|c|c|c|c|c|}
\hline Specimen & $\begin{array}{c}\text { Initial } \\
\text { mass, } \mathrm{m}_{\mathrm{i}} \\
(\mathrm{g})\end{array}$ & $\begin{array}{c}\text { Final } \\
\text { mass, } \mathrm{m}_{\mathrm{f}} \\
(\mathrm{g})\end{array}$ & $\begin{array}{l}\text { Machining } \\
\text { time (min) }\end{array}$ & $\begin{array}{c}\text { MRR } \\
\text { (g/min) }\end{array}$ \\
\hline 1 & 41.8 & 40 & 3.12 & 0.576 \\
\hline II & 40.8 & 39 & 3.1 & 0.58 \\
\hline III & 36.4 & 35 & 3.12 & 0.451 \\
\hline IV & 39.8 & 38 & 3.09 & 0.582 \\
\hline $\mathrm{V}$ & 36.5 & 35 & 3.11 & 0.482 \\
\hline $\mathrm{VI}$ & 37.6 & 36 & 3.13 & 0.511 \\
\hline VII & 38.4 & 37 & 3.13 & 0.457 \\
\hline VIII & 38.5 & 37 & 3.12 & 0.448 \\
\hline IX & 37.4 & 36 & 3.11 & 0.45 \\
\hline
\end{tabular}

\section{E. Surface Roughness}

Surface roughness cannot be obtained as smooth in any manufacturing process. Some deviations or irregularities will occur. The irregularities on the surface will be in the form of successive hills and valleys which are varying in height and spacing. These irregularities are called as surface roughness or surface finish.

\section{Surface Roughness Tester}

Surface roughness tester is used to measure the surface roughness or surface finish of the materials. The roughness tester measures the roughness value in microns $(\mu)$.
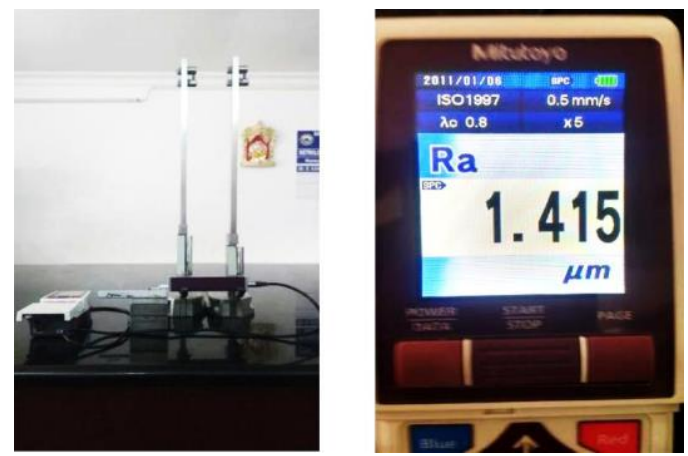

Figure 8 Surface roughness tester

Table 11 Surface roughness measurement

\begin{tabular}{|c|c|c|c|c|}
\hline Specimen & Trial 1 & Trial 2 & Trial 3 & $\begin{array}{c}\text { Surface } \\
\text { Roughness }(\boldsymbol{\mu})\end{array}$ \\
\hline I & 1.418 & 1.275 & 1.271 & 1.321 \\
\hline II & 1.71 & 1.924 & 1.938 & 1.857 \\
\hline III & 1.301 & 1.433 & 1.663 & 1.465 \\
\hline IV & 1.788 & 1.972 & 2.054 & 1.938 \\
\hline V & 0.895 & 0.841 & 0.873 & 0.87 \\
\hline VI & 0.857 & 0.892 & 0.848 & 0.866 \\
\hline VII & 1.246 & 1.165 & 1.242 & 1.218 \\
\hline VIII & 2.093 & 2.301 & 2.793 & 2.395 \\
\hline IX & 1.62 & 1.415 & 1.373 & 1.469 \\
\hline
\end{tabular}

The composite having composition $95 \% \mathrm{Al}+5 \% \mathrm{CSA}$ is having the maximum material removal rate and the composite having the composition $90 \% \mathrm{Al}+4 \% \mathrm{~B} 4 \mathrm{C}+4 \% \mathrm{CSA}$ showing the maximum surface roughness.

\section{Conclusion}

After the conduction of various tests and obtaining the results, we can come to a conclusion that the Aluminium Matrix composite which contains both boron carbide and coconut shell ash as its reinforcements has improved mechanical as well as tribological properties when compared to individual aluminium alloy.

\section{References}

[1] Balakrishnan. P, John. M. J, Pothen. L, Sreekala. M. S, Thomas. S "Natural fibre and polymer matrix composites and their applications in aerospace engineering", Journal of Materials and Research

[2] Biswajit Panda, Amit Kumar Mahato, Challarapu Varun \& Siva Sankara Raju "Wear Behavior of Aluminum Based Composite Reinforced with Coconut Shell Ash", Imperial Journal of Interdisciplinary Research, Vol-2, Issue-5, 2016 ISSN: 2454-1362

[3] David Raja Selvam. J, Robinson Smart. D.S. Dinaharan.I "Synthesis and characterization of Al6061-Fly Ash-SiC composites by stir casting and compo casting methods", 10th Eco-Energy and Materials Science and Engineering (EMSES2012), ELSEVIER Energy Procedia 34 (2013) $637-646$

[4] Dileep. T, Srinivas. P. N. S “Enhancement of mechanical, microscopic and tribological properties of hybrid metal matrix composite reinforced with alumina, graphite and silicon carbide", International Journal of Latest Engineering Research and Applications, ISSN: 2455-7137 Volume - 01, Issue - 04, July - 2016 PP - 41-49 www.

[5] Frida Andersson, Astrid Hagqvist, Erik Sundin and Mats Björkman "Design for Manufacturing of Composite Structures for Commercial Aircraft - the Development of a DFM strategy at SAAB Aero structures", Variety Management in Manufacturing Proceedings of the 47th CIRP Conference on Manufacturing Systems, ELSEVIER Procedia CIRP 17 (2014) $362-367$

[6] Himanshu Kalaa, Merb K.K.S, Sandeep Kumar "A review on Mechanical and Tribological Behaviours of Stir Cast Aluminum Matrix Composites", 3rd International Conference on Materials Processing and Characterization, ELSEVIER Procedia Materials Science 6 (2014) $1951-1960$

[7] Kalaiselvan. K, Murugan. N, Siva Parameswaran "Production and characterization of AA6061-B4C stir cast composite", Materials and Design, ELSEVIER 32 (2011) 4004-4009

[8] Kenneth Kanayo Alaneme, Henry Ikechukwu Eze, Michae Oluwatosin Bodunrin "Corrosion behavior of groundnut shell ash and silicon carbide hybrid reinforced $\mathrm{Al}-\mathrm{Mg}-\mathrm{Si}$ alloy matrix composites in $3.5 \% \mathrm{NaCl}$ and $0.3 \mathrm{M} \mathrm{H} 2 \mathrm{SO} 4$ solutions", Leonardo Electronic Journal of Practices and Technologies, ISSN 1583-1078 Issue 26, January-June 2015 p. 129-146

[9] Kenneth Kanayo Alaneme, Joshua Ogheneakporobo Ekperusi, Samuel Ranti Oke "Corrosion behaviour of thermal cycled aluminium hybrid composites reinforced with rice husk ash and silicon carbide", Journal of King Saud University, Engineering Sciences

[10]Kenneth Kanayo Alaneme, Michael Oluwatosin Bodunrin, Adebimpe Awe. A "Microstructure, mechanical and fracture properties of groundnut shell ash and silicon carbide dispersion strengthened aluminium matrix composites" Journal of King Saud University, Engineering Sciences

[11] Lakhvir Singh, Baljinder Ram, Amandeep Singh "Optimization of process parameter for stir casted aluminium metal matrix composite using Taguchi method", International Journal of Research in Engineering and Technology, eISSN: 2319-1163 | pISSN: 23217308

[12]Madakson. P. B, Yawas. D. S, Apasi. A "Characterization of Coconut Shell Ash for Potential Utilization in Metal Matrix Composites for Automotive Applications", International Journal of Engineering Science and Technology 